\title{
Motives Affecting History Writing During the Period from Second Century to Fifth Century AH, as an example $(*)$
}

\author{
Dr. Saleh Muhammad Zeki Mahmood Al - Leheabi \\ Assistant Professor - Department of History and Islamic Civilization \\ University of Sharjah - United Arab Emirates
}

\begin{abstract}
This research deals with a very important subject. It focuses on the Factors affecting history writing, by Moslem historians, during the first five centuries $\mathrm{AH}$. This era constitutes the foundation stage for the Moslem state. It is the most notable era in Islamic history writing. A big number of historians appeared in this period, and they established the criteria of Islamic history writing.
\end{abstract}

The subject is of paramount significance. The research relies on a descriptive and analytical discussion of a huge number of historic resources, documents and texts. The research describes the role of motives controlling the attitudes and thought of Moslem historians. In addition to the impact of such motives, fully or partially, on the writing techniques and scientific attitudes of the historians.

The main question is to what extent such motives became clear in the

(*)The Egyptian Historian, No: Sixty -fifth, January 2020. 
writings of Moslem historians in the first five centuries AH. How they affected the progress of history writing, and what are the types and categories of such motives.

In this research we will use the analytical and descriptive approach to deal with the subject in all its aspects, and to the reach required answers.

Key words: (Motives , History, writing, historians)

\section{The structure of the research is as follows:}

\section{First Topic: Religious and Intellectual Motives.}

1 - 1 Impact of religious motives on history writing.

$1-2$ Analysis of types of Historians.

$1-3$ The impact of sectarianism in writing history

\section{Second Topic: Political, administrative and economic} Motives

$2-1$ Politics, management and economics as an influential factor in history writing.

2 - 2 Appearance of Historians interested in politics, management and economics

2 - 3 The reciprocal relationship between the historian and the authority:

\section{Third Topic: Social \& Scientific Motives}

3 - 1 Social \&Scientific Motives and their impacts on History writing 


\section{Dr. Saleh Muhammad Zeki Mahmood Al - Leheabi}

\section{3 - 2 Cultural and scientific Diversity and its effect on historical environment}

We will use a number of resources, references in addition to most recent studies.

\section{First Topic: Religious \& Intellectual Motives}

\section{1 - 1 Impact of religion on History Writing}

No doubt, religious motives formed the corner stone of history writing in the first centuries of Islam. This was inevitable and natural as the state at that era was a religious one. Religion covered all aspects of life. This for sure was reflected clearly on history writing. Particularly, because history writing is concerned with community and life in all its details .Therefore, all purpose and motives were used to serve religion.

A scrutinizing look at the initial resources of Islamic history, will guide us to the fact that history writing was purely religious .Narrators interested in the history of nations since the start of life, were trying to know how the wisdom and power of God affected them ${ }^{(1)}$.

In addition to the above, such historians, were affected by other religions existing before Islam such as Judaism \& Christianity .The stories of people of the book covered vast spaces in the writings of first Moslem historians, under the name of Israelites ( narratives originating from Jewish traditions ). This can be found in the stories on the start of creation or prophets stories, or stories of previous nations. This was used by story tellers, interpreters and 
others in their effort to give complementary image of history writing ${ }^{(2)}$.

The above mentioned can be found clearly in the narrations of some of historians and Hadith scholars during the first five centuries (AH) . The first of them was Mohammad Bin Asmaeel Al Bukhari (died in $256 \mathrm{AH}$ ). He adopted an accurate approach in transmitting narratives and in authoring books in Hadith and History. He said in the chapter (What was narrated about the Israelis) that the prophet (PBUH) said: "Convey (my teachings) to the people even if it were a single Aayah (Verse, sentence), and tell others the stories of Banee Israa'eel (which have been taught to you), for it is not sinful to do so. And whoever tells a lie on me intentionally, will surely take his place in the (Hell) Fire." (3)

The historic writings of religious motives appeared early, by Wahab Bin Monbih (died in 114). He was well known for being appointed as a judge in Sanaa/ Yemen, and for his knowledge of jurisdiction .He used to write about doctrines and religious aspects, in addition to his interest in history. ${ }^{(4)}$

Also, we can understand the above from the biography of Obaid Bin Shariya AlJorhmi (lived in the first Hegra (Islamic calendar) century, date of his death isn't certain). He was well known as a narrator of the narratives of old Arabian kingdoms before Islam. Moawiya Bin Abi Sofyan invited him to come from Yemen to Damascus to hear from him the narratives of previous nations and populations, and to benefit from their news, situations, and 


\section{Dr. Saleh Muhammad Zeki Mahmood Al - Leheabi}

consequences .He remained alive till the era of the Caliph Abdul Malik Bin Marwan (65 - 86 AH) .He authored the book Al Molok wa Akhbar Al Madheen "Kings and news of previous nations). ${ }^{(5)}$

Such religious and cultural considerations resulted in the appearance of historic schools. Each played a certain role, and each had its approach .They are the school of AlMadina Al Monawara, and the school of Iraq (AlKofa and Al Basra) .The school of AlMadina was known for the clear religious dimension, focusing on the two fields of Hadith and expeditions and biographies. As for the school of Iraq it was famous for the appearance of news narrators and the scholars interested in general history, and genealogy. ${ }^{(6)}$

\section{$1-2$ Analysis of types of Historians:}

Looking into the biography of a number of historians and the approach adopted by them, we can determine the impact of religious and intellectual motives on their writings, for example:

\section{1 - Amer Bin Shraheel Al Shaabi (died approximately in 104AH):}

One of the leading historians who focused on narratives of expeditions and conquests. His narrations are scattered in many books .However, analyzing his narrations and his techniques, we discover that the religious factor was very strong. ${ }^{(7)}$

\section{2 - Mohammad Bin Shihab Al Zuhri (died in 124 AH):}

One of the most famous Hadith scholars. He narrated many 
historic narratives included in prophet's biography books and Hadith books.

Historic sources show us that Al Zuhri developed interest in Hadith and prophet's biography as a result of a dispute with his Shaikh on Fiqh. Afterwards, Al Zuhri got in touch with Saeed Bin Al Musaib, and influenced by him, he started thinking of compiling the biography of the prophet as an integral part of religion. ${ }^{(8)}$

\section{3 - Mohammad Bin Ashaq (died in 151AH):}

Ibn Ishaq was the first to compile, specifically, Al Sera Al Nabawiya (the biography of the prophet). This is proved through his book Serat Rasool Allah (biography of the prophet), which we find its narrations in the books of Al Sera (biography of the prophet), as well as his book (Al Maghazi "expeditions"). His books show the religious motives. His books included narratives of people of the book, historical events that took place before the era of the prophet (PBUH), then expeditions and biography of the prophet, proving his clear and express religious motives, which are the basics of his history writing. ${ }^{(9)}$

\section{4 - Mohammad Bin Ismaeel Al Bukhari (256 AH):}

His book Al Tarikh Al Kabir (the grand history) proves clearly his religious motives .It is a biography of narrators of Hadith. Later, he will use this book to author his most important book Sahih Al Bukhari. His arrangement of the book shows his religious background, as he put the biography of anybody with the name of Mohammad at the start of the book, starting with the prophet 


\section{Dr. Saleh Muhammad Zeki Mahmood Al - Leheabi}

Mohammad (PBUH) in appreciation and respect of his position, and then anybody called Mohammad. ${ }^{(10)}$

\section{$1-3$ The impact of sectarianism in writing history}

Throughout the history, Muslim community has witnessed the emergence of new creeds and doctrines, each of which had its own point of view of history and it's own judging angles.

It was noticed that some events were distorted from their reality, some were added to, some were totally made up! Particularly the religious differences that were based on the perception of the rightful person to rule the people in all matters including their faith under the name of Caliphate.

This has significantly influenced the people who are interested in promoting their views, fanatics and doctrines through their interpretation of history in a way that meets their ambitions and satisfy their doctrinal and ideological aspirations, especially after the huge conflict between the Umayyads and Alawites that created writers revere the Alawites and therefore adopted the Shiite thought in the writing of history, and other writers adopted the advocacy of the Umayyads as they are the rightful rulers and obeying them is a legal obligation from their point of view. The same happened when the dispute occurred between the Umayyad and Abbasid, a group of writers were supporting the Abbasid and came up with their own doctrine theory and they used it to undermine the religious idea that the Umayyads were using to empower themselves. 
These sectarian, doctrine and ideological affiliations of the historians have influenced their writing of history, for example:

Aban bin Taghlib bin Rubah (died $141 \mathrm{AH})^{(11)}$

Ibrahim bin Isaac Al Ahmari Al Nahawandi (was alive 269 $\mathrm{AH})^{(12)}$

Ibrahim bin Mohammad bin Saeed Al Thaqafi (died $283 \mathrm{AH})^{(13)}$

Ahmad bin Ibrahim bin Abi Rafee Al Saymri (lived in the $5^{\text {th }}$ Hijri century ) ${ }^{(14)}$

In his discussion on the negative impact of the sectarianism and doctrine on historical writing, Ibn Khaldun says: "Since transferring the news may have some untruth to it for various reasons, one of which being the reporters own believes and sectarianism, but if the reporter were to be fair and truthful, he would investigate till he confirms the news. On the other hand, if he was fanatic about his own believes and sectarianism then he would tell the news that he agrees with, which will prevent him from criticizing and looking for the truth and he will fall into the trap of accepting and participating in the lie." (15)

Examples of famous historians during the first five Hijri centuries who their historical writings were influenced by their sectarianism and doctrine:

\section{1- AlWaqidi:}

Mohammed bin Omar bin Waqid Al Sahmi Al Aslami, died in $207 \mathrm{AH}$, one of the most famous and oldest Muslim historians, was 


\section{Dr. Saleh Muhammad Zeki Mahmood Al - Leheabi}

born in Al Madina and he lived their till he moved to Iraq in $180 \mathrm{AH}$ during the ruling of Harun Al Rashid, has several books, including: Al Maghazi Al Nabawia, Fatih Ifriqia, Akhbar Mecca, And others. ${ }^{(16)}$

It is noted in his writings the impact of the religion and sectarianism motivation and the doctrinal change, as mentioned by $\mathrm{Al}$ Nadim in the Fihrast. ${ }^{(17)}$

\section{2- Ibn Hisham:}

Abdul Malik bin Hisham bin Ayyub Al Humairi Al Maafari (died $213 \mathrm{AH}$ ), was an expert in genealogy, language and the history of the Arabs, was born in Basra and died in Egypt, has several books, including: Al Tijan Fi Molok Al Hameer, and his most famous work was Al Seera Al Nabawia (biography of the Prophet), his writings shows the religious and tribal socialism influence. ${ }^{(18)}$

\section{3- Al Yaqubi:}

Ahmed bin Isaac Al Yaqubi died after $292 \mathrm{AH}$, went to Morocco, visited Armenia and moved between many countries, has several books, including: Tareekh Al Yaqubi, Akhbar Al Umm Al Salifa and others. ${ }^{(19)}$

His writings show his political and sectarianism that were evident in many of his events analyzes.

\section{4- Al Masoudi:}

Abu Al Hasan Ali bin Al Husain bin Ali Al Masoudi, died in $346 \mathrm{AH}$, he was from Baghdad, but lived and died in Egypt. 
Has several books, including: Morooj Al Dhahab and Maaden Al Jawhar, Akhbar Al Zaman wa man Abadah Al Hadathan and others. ${ }^{(20)}$

His writings were clearly influenced by his religious ideas, although he sought to follow his vision as a neutral historian but his writings were nevertheless affected by him being from Al Mu'tazila.

\section{Second Topic: Political, Administrative \& Economical Motives $^{(21)}$ :}

\section{2 -1 Politics, Management and Economics as influential factor in History Writing:}

A simple examination of history writings during first five century (AH): Islamic Calendar) shows us the strong attention of historians to political, administrative

And economic motives. One can see the effect of such motives on their writings, either through their points of views, attitudes, and visions, or through narrating through others, and adoption of some concepts deemed by them to be best suited for the development and progress of the community, if fully utilized. Moslem historian was affected by different schools, such as the schools of transmitting the narratives of other nations that preceded the Islamic state or coincided with it. They provided us with a collection of books, or verbal heritage. They transmitted such narratives, depending on them fully or partially, then, they added to them, and commented on them.

The huge changes witnessed by the first five centuries $\mathrm{AH}$, left 


\section{Dr. Saleh Muhammad Zeki Mahmood Al - Leheabi}

a clear effect on the general concept of the course of history and history writing, in addition to the impact of disputes, trends and inclinations on such writings. The mentioned changes affected all parts of the Islamic world and influenced hugely history writing in all aspects including the political, administrative and economic ones.

The notable development of Islamic state and the major structural changes in the management and economy of the state from the first Hegra century till the fifth century, lead to the emergence of a group of authors interested in writing on the management and economy of the state ${ }^{(22)}$. For example there were historians interested in administrative aspect, and theorization for the establishment of the caliphate, how it should be, along with providing advice to the Caliph, ministers, ambassadors, tax collectors and other officials. They used to avoid mentioning names in many cases, to avoid doing harm or embarrassment to persons, to ensure the continuity of their work, continuity of its benefit, and to avoid anybody criticizing them ${ }^{(23)}$.

Also, there was interest in the most accurate aspects of life that can be used to develop the management, like describing the nature of clothes of people working in the management, how they receive delegations and persons, the use of translators, types of writing tools, and shapes of stamps. In addition to taking, historic examples transmitted from other nations like the Romans, Persians, Chinese and Indians, because such nations achieved a lot in politics, management and economy. ${ }^{(24)}$ 


\section{2- 2 Emergence of Historians interested in Politics, Management and Economy:}

History writing for political purposes was notable in many books. Such purposes vary .Sometimes they are for religious purpose as required by the caliph who issues his orders to write for such purpose .He might order a certain scholar to write in a specific subject. For example, Imam Al Zuhri wrote under the order of the Omayyad Caliph / Hisham Bin Abdulmalik (105 - 125 AH), after the occurrence of political problems, which, mainly, took religious and intellectual forms. According to the caliph, the subject shall be dealt with, and then he ordered Imam Zuhri to write ${ }^{(25)}$. Ibn Kathir and other scholars accepted this opinion .He said "Caliph Hisham Bin Abdulmalik compelled Al Zuhri to write Hadith, and then afterwards people started writing" (26). Ibn Saad narrated from Al Zuhri that he said: "We used to hate to write the science of Hadith, till these princes compelled us to write, then our opinion became that no Moslem shall prevent this work". ${ }^{(27)}$

$\mathrm{Al}$ Yaqopi deemed that this was a defect in the part of Al Zuhri because he wrote under such order which was utilized for un suitable political purposes; in his opinion .This opinion was not shared by other historians, as $\mathrm{Al}$ Zuhri and others were writing Hadith and biography of the prophet before that time. ${ }^{(28)}$

Ibn Hisham said something similar .He clearly stated in his introduction: "abandoning some of the narratives mentioned by Ibn Ishaq in this book, which wasn't mentioned by the prophet (PBUH), 


\section{Dr. Saleh Muhammad Zeki Mahmood Al - Leheabi}

nor stated in the holy Quran. In addition to that Al Zuhri mentioned poems which were not known to people who are well versed in poetry, other narratives are not decent to talk about, and others, some people would like to ignore". ${ }^{(29)}$ This is a clear declaration by Ibn Hisham on the biography of Ibn Ishaq, which was highly motivated; Horvitz stated that those "some people" are the Abbasids. ${ }^{(30)}$

Also, sources pinpointed to the ordeal of Ibn Saad, the author of "Al Tabaqat", by the Abbasid Caliph Al Mammon (198 - 218 AH) resulting from the sever trail of the creation of the Quran, subsequently, he was forced to acknowledge the creation of the Quran. ${ }^{(31)}$

In other sources we found him far away from this idea, trying to be neutral, avoiding fantasy, and of clear motives and objectives. ${ }^{(32)}$

As for books on management and economics, and the motives behind them, we discover various and exceptional scientific features. The first is the effort of the historians to prepare a comprehensive concept of the nature of administrative and economical changes in the Islamic state. How the state developed from a stage to another. This can be deduced, by a scrutinizing look at the book of Al Balathri "Conquests of countries, Fotoh Al Boldan), and the accurate statistics included therein, and how they were used. ${ }^{(33)}$

Also, we can see the administrative and economic motives and objectives in the book of (Al Kharaj, land tax) which included many historic narratives, explaining the author's interest in preparing exceptional management and economic features, which can be of benefit to the Abbasid Caliph, in the management of the state. ${ }^{(34)}$ 
Ibn Ishaq did his best to make the administrative and economic features clear. They constituted one of the engines used in writing the biography of the prophet. He mentioned many narratives on the execution of management and economy at the era of the prophet. $\mathrm{He}$ pinpointed treaties, alliances, reconciliation conditions, and resulting economic repercussions. ${ }^{(35)}$

Ibn Hisham was great in the refinement of the biography of Ibn Ishaq. He clarified. ${ }^{(36)}$

That the administrative and economic aspects were his most important objectives. He arranged the biography of the prophet, organized its information in a way that clarifies the administrative and economic importance of historic information, such as arranging the names of princes, workers, their salaries and wages and so forth.

\section{2-3 The reciprocal relationship between the historian and the authority:}

Through exploring the writings of historians during the first five Hijri centuries it is noted that there was a clear impact on the historians by the authorities and their sectarianism, ideologically and politically, especially what happened between the Abbasids and the Umayyads, which led to the overthrow of the Umayyad state and the establishment of the Abbasid state in $132 \mathrm{AH}^{(37)}$, all this led to the emergence of a tendency to strengthen the position the Abbasids, who destroyed their ancestors the Umayyads, chased them everywhere, and committed massacres against them till they were exterminated. ${ }^{(38)}$

The reader of famous historians' writings, especially those who 


\section{Dr. Saleh Muhammad Zeki Mahmood Al - Leheabi}

were in the third, fourth and the fifth Hijri centuries will notice clearly that they were influenced by the authorities and in line with its decisions, even some of those historians have become advisers and consultants to the caliphs, and as an example one can refer to the writings of AlTabari, AlMawardi and Abi Yali to see how the historians were in harmony with the authorities. ${ }^{(39)}$

Many of these historians did not face any difficulties in writing history because of their harmony with the Abbasid state. Their writings showed no flows or documented no mistakes the Abbasid had done, although there were lots to be pointed out. ${ }^{(40)}$

If we look into one of the most famous historians, Al Mawardi (died $450 \mathrm{AH}$ ), we will find that he was part of the Abbasid authority, he was one of the most famous judges in their era, and one of the most famous jurists; which makes it obvious that his religious view and connection to the authorities had affected his writings that all came in the form of advises and consultation to the rulers and how to work politically and diplomatically. ${ }^{(41)}$

And so did Abu Yali Al Firaa (died 458 AH), who was close to the Abbasid caliphs, especially the Caliphs Al Qadir and Al Qaim, where Caliph Al Qaim appointed him a judge in Dar Al Khilafa, and we can see how his relationship with the Abbasid authority influenced him through his writings, which took an advisory nature, such as the book: Al Ahkam Al Sultania, and Rusul Al Molook Wa Man Yasluh lil Resalati wa Al Safarah.

\section{Third Topic: Social \& Scientific Objectives}




\section{3 - 1 Social and scientific motives and their effect on history writing $^{(42)}$ :}

Through the scrutiny of historic texts, we found out clear social objectives, behind the writing or the use of various information .The purpose of the historian was to support or negate a certain social situation.

For example, we can see the interest of Asem Bin Omar Bin Qutada Al Ansari in exposing the role of his people and the role of his tribe in supporting and defending Islam. He mentioned in details Al Aws and Al Khazrang, how were their situations, how they embraced Islam, their role, the position of $\mathrm{Al} A$ nsar in supporting Islam and supporting the prophet (PBUH), how they pledged allegiance to him in Mecca. ${ }^{(43)}$ How they helped him to migrate to Al Madina, how they received and welcomed him .Then, how the prophet interconnected with his uncles Bani Al Najjar, and became their leader, how they affected him, consequently he loved them and never left them until the conquer of Mecca .They became his people, embraced him and defended him. ${ }^{(44)}$

He focused on the Hadith of the prophet informing the Ansar "by God if people took a certain path and Al Ansar took another, I will lead the path of the Ansar".

We face the same situation in what was transmitted by $\mathrm{Al}$ Tabari from Mosa Bin Oqba whose grandfather on the side of his mother, Abu Habiba, slave of Al Zubair Bin Al Awam .We found out clearly his solidarity with $\mathrm{Al} \mathrm{Al} \mathrm{Zubair,} \mathrm{and} \mathrm{his} \mathrm{defending} \mathrm{their}$ 


\section{Dr. Saleh Muhammad Zeki Mahmood Al - Leheabi}

position against the Omayyad, due to social relation. ${ }^{(46)}$

Also, we can track in some other narratives by Al Tabari that some historian embraced social objectives, such as Awana Bin Al Hakam, who was backing his tribe Bani Kalb. ${ }^{(47)}$

Therefore, and through a number of testimonials in the history of Al Tabari, and other history books, particularly, the books of genealogy, classes and biographies, we can see the influence of social objectives on the attitude of historians in their books.

\section{2 - 2 Cultural and Scientific Diversity and its impact on Historic} Environment:

Scientific and cultural objectives played a distinguished impact on history writing. We come across many books and narratives written for scientific and cultural purposes. Therefore, we find them sometimes of different nature due to the purpose of their writing.

For example, and through tracking some of the narratives of Ibn Hajar Al Asqalani in his book Tahtheeb Al Tahtheeb, we found out in his narration on Mosa Bin Aqba who was known of his writing of biographies and conquests, that his objectives of writing is the verification of accuracy of information, and purifying them of confusion, obscurity and errors. ${ }^{(48)}$ Also, he narrated to us, how he was relying on a scientific approach based on written documents. ${ }^{(49)}$ Such scientific features was enjoyed by him and was existing in his family. ${ }^{(50)}$

Such scientific accuracy made Imam Malik to recommend his science when he was asked : "from whom shall we take conquest? 
he said, you should take the conquests from Shaikh Al Saleh Mosa Bin Oqba, as they are the most true conquests known to us. In a narrative: he was trustworthy. Khalifa said: Ibn Oqba died in the year one hundred forty one AH." (51)

We might see the scientific objective in the writing of biography of the prophet and conquests by Al Zuhri, who was known for his utmost care on the adoption of scientific approach .He, described himself as saying "nobody authored this science like me, and nobody rendered efforts like me". (52) Also, he utilized the transmission from other sources as indicated by him, to ensure the compliance with scientific approach, as he transmitted from the conquests of Orwa bin Al Zubair. ${ }^{(53)}$ It is noted that Al Zuhri rendered his best efforts to show the controls of history writing ${ }^{(54)}$.

As a part of historic knowledge. For example, he narrated that the start of reliance of history on narratives started from the era of Ibraham and Ismaeel, till the year of the Elephant, and the date of the birth of prophet $(\mathrm{PBUH})$.

It was transmitted by him that the prophet (PBUH) was the first to adopt Islamic calendar, after entering Al Madina in the month of Rabee Al Awal, as Muslims were using the dates by one month and by the two months from the coming of the prophet till the completion of the year ${ }^{(55)}$.

Notes: 


\section{Dr. Saleh Muhammad Zeki Mahmood Al - Leheabi}

(1) Please see: Dawood Salman Khalaf Hanad Al Zubaidi,( 2001 ) Impact of Hadith on history writing till the end of third century AH., Baghdad University, Master's thesis typed on typewriter, submitted to faculty of education (Ibn Roshd), p. 54 and after.

(2) Please see: Abu Al Fidaa Ismaeel Bin Omar Bin Katheer (died in 774AH) ( 1974),Bidaya WA nihaya, Cairo, chapter 9, and page 276.

(3) Abu Abdullah Mohamad Bin Ismaeel Al Bukhari (died in $256 \mathrm{AH})$ (1422 AH), Sahih Al Bukari, Verification by: Mohammad Zuhair Bin Naser Al Naser, edition 1 ,Beirut, Touq Al Naja house Hadith No. 3461.

(4) Mohammad Bin Maneei Bin Saad (died in 230 AH) Al Tabaqat Al Kobra ,Beirut, Sader House, chapter 5, p. 395.

(5) Mohammad Bin Ishaq Bin Al Nadeem (died approx. 385 AH) Al Fahrast, edition 1 ,Cairo, p. 138.

(6) Al Zubaidi, Athar Al Hadith, p. 58.

(7) Abu Naeem Ahmad Al Asbahani (died in 430 AH)(1967) Hilyat Al Awliyaa wa Tabaqat Al Asfiyaa, Beirut, Edition 1, chapter 5, pp. 310 - 328.

(8) Mohamad Ata Allah Mohammad Saeed , ( 1996 ), Intentions of Muslim historians in writing biographies in the second and third centuries $A H$, , Baghdad university, Master's thesis, typed on typewriter, submitted to Council of faculty of literature, p. 87 and afterwards.

(9) Al Tabari, Abu Jaafar Hamad Bin Jarir (died in 310 AH) (1387 AH), Tarikh Al Rosol wa Al Molok, Beirut, heritage house, Edition 2, chapter 1, p. 433.

(10) Mohammad Bin Omar Al Waqdi (died in 207 AH) ( 1996), Al Maghazi, verification by: Marson Jhons, Cairo, Edition 1 , chapter 1, p. 235.

(11) Al Dhahabi, Sear Aalam Al Nubalaa, part 6, page 308.

(12) Al Najashi, Al Rijaal, page 19. 


\section{Motives Affecting History Writing During the Period}

(13) Al Nadeem, Al Fihrast, page 279.

(14) Al Najashi, Al Rijaal, page 84.

(15) Ibn Khaldoon, Al Muqaddemah, page 87.

(16) Ibn Khalkan, Wafayat Al Ayan, part4, page 348.

(17) Page 111.

(18) Ibn Hajar. Al Durrar Al Kamina, Part2, Page 415.

(19) Al Zurkali, Al Alaam, Part1, Page 95.

(20) Al Dahabi, Mizan Al Etidal, Part4, Page 253.

(21) Please see: Saeed, Maqased Al Moaarikheen (Intentions of Historians), p. 148 and after.

(22) Please see for example : Ahmad Bin Abi Yaaqob Al Yaaqobi (died in 259 AH),( 1995 ), Al Tareekh ,Beirut, verification by : Mohammad Yousef Najm , edition 1, Sader publishing and printing house ,, Ahmad Bin Yahya Bin Jaber Bin Dawood Al Balathri (died in 279 AH ),(1988), Ftooh Al Buldan, Beirut, (Conquests of countries) AlHilal House and book shop ,.

(23) Please see: Abu Mohamad Abdullah Bin Moslem Bin Qutaiba Al Dinori (died in 276 AH), (2010), Oyoon AlAkhbar, Beirut, Edition 1 ,Scientific books House.

(24) Please see : Abu Ali Ahmad Bin Mohammad Bin Yaqob Misqwei(died in 421 AH ) ,(2003), Tajareb Al Omam wa Taaqob Al Himam, Verification by : Said Kasrawi Hasan, Beirut, Edition 1, Scientific books house ,.

(25) Saeed, Intentions of Historians, p. 150.

(26) Ibn Katheer, AlBidaya wa Al Nihaya, Chapter 9, p. 345.

(27) Ibn Seed, Al Tabaqat, chapter 2, p. 345.

(28) Abdulaziz Al Dori, (1981), A research on the establishment of science of history by the Arabs, edition 1 ,Beirut, Al Mashriq house p. 101, Saeed, 


\section{Dr. Saleh Muhammad Zeki Mahmood Al - Leheabi}

intentions of historians, p. 150.

(29) Abdulmalik Bin Hisham Al Mafri (died in 213 AH ), (1955)Prophet's biography, Verification by : Mostafa Al Saqa, Ibrahim AlIbyari, and Abdulhafith Al Shalabi , Egypt, Edition 1, Mostafa Al Babi Al Halabi and sons bookshop, printing press and company, chapter 1, p. 12.

(30) Yousef Horvitz, first conquests and their authors , (1949), translation:Husain Nasar, Cairo, edition 1, printing press of Mostafa Al Babi Al Halabi and sons , page 83 , Saeed, intentions of historians, p. 163.

(31) Al Tabari, Tarikh Al Rosol and Al Molok, chapter 8, p. 634.

(32) Saeed, Intentions of Historians, pp. 164 - 165, please see: Ibn Saad, AlTabaqat, chapter 2, p. 242 and after.

(33) Al Balathri, Conquest of countries, Mohamad Jasim Hamadi, MawaridAbalathri on Omayyad Dynasty on writing genealogy of noble's, Baghdad University, Doctorate degree, typed on type writer, submitted to faculty of literature.

(34) Abu Yousef Yaqob Bin Ibrahim Bin Habib Al Ansari (died in $182 \mathrm{AH}$ ) Al Kharaj (Land tax), Egypt, Verification by: Taha Abdolraoof Saad, Saad Hasan Mohammad, Al Azhariya heritage bookshop).

(35) Saeed, intentions of historian, p. 190.

(36) See for example: Ibn Hisham, A lSera, chapter 2, pp. 131, 140, and 182.

(37) Look AlTabari, Tareekh AlUmm, Part9, Page 391 and forward.

(38)Look: AlMasoudi, Morooj AlDahab, Part3, Page 163.

(39) Look: Al Tabari, Tareekh Al Umm wa Al Molook, Al Mawerdi, Al Ahkam Al Sultania, Abu Yali Al Feraa, Rusul Al Molook.

(40) Hussain Asi, Abu Jaafar Mohammad Bin Jareer AlTabari and his book Tareekh Al Umm Wa Al Molook, No print, (Beirut, Dar Al Kutob AlElmia) 


\section{Motives Affecting History Writing During the Period}

Page 46 and forward.

(41)Look: Dorrar Al Sulook Fi Siyasat Al Molook, Al Ahkam Al Sultania.

(42) Please see: Saeed, intentions of Moslem historians, p. 152 and after.

(43) Please see: Saleh Muhammad Zeki Al Leheabi,( 2007), Prophetic arrangements, based on Sahih Al Bukari, Dubai, edition 1, Dubai international Quran Award, pp. 13 - 27.

(44) Please see: Saleh Muhammad Zeki Al Leheabi, , (2014) Administrative and economic systems in prophet's era, based on Sahih Moslem, Dubai, edition 1, Al Ajwad publishing and distribution establishment, pp. 55 - 71 .

(45) Narrated by Bukari and others in other wording, Al Sahih, Hadith No. 4333.

(46) Please see Al Tabari, Tarikh Al Rosol wa Al Molok, chapter 4, p. 453 , Shams Al Dein Abu Abdullah Mohammad Bin Ahmad Al Thahabi ( died in 748 AH ),(2003 ), Tarikh Al Islam wa Wafiyat Al Mashaheer wa Al Aalam, Verification by : Dr. Bashar Awad Maarof , Beirut, edition 1, Dar AlGharb Al Islami chapter 2 , p. 706; Abu Al Fadhl Ahmad Bin Ali Bin Hajar Al Asqalani (died in $852 \mathrm{AH}$ ), (2002 ), Lissan Al Mizan, Verification by: Abdulfatah Abu Ghada, Beirut, edition 1, Dar Al Bashaer Al Islamiya , Nasar , Establishment of historic writing by Arabs, p. 67 and after, Saeed, intentions of historians, pp. $153-154$.

(47) Please see, Tarikh Al Rosol, chapter 3, p. 209, Al Balathri, Fotoh Al Buldan, page 305 .

(48) Please see: Saeed, intentions of historians, p. 112 and after.

(49) Chapter 10, p. 361 and after.

(50) Ibn Saad, Al Tabaqat, chapter 2, p. 293.

(51) Abu Zakariya Mohyedein Yahya Bin Sharaf Al Nawawi (died in $676 \mathrm{AH}$ ), Tahtheeb Al Asmaa WA Alloghat,Egypt, Sharakat Al Olama WA Idarat Al 


\section{Dr. Saleh Muhammad Zeki Mahmood Al - Leheabi}

Tibaa Al Munirya ,chapter 2, p. 118.

(52) Please see: Ibn Hajar, Tahtheeb Al Tahtheeb, Chapter 9, p. 449, Saeed, Intentions of historians, pp. $113-114$.

(53) Al Thahabi, History of Islam, p. 227.

(54) Al Tabari, Tarikh Al Rosol, chapter 2, p. 390 and after.

(55) Chapter 2, p. 388, Al jobori, Al Zuhri, p. 7 and after.

There are many forms of history writing, however, we 
believe that the above mentioned is good enough.

\section{Summary:}

Based on the above with regard to motives affecting history writing during for example the period, from the second to the fifth century $(\mathrm{AH})$, we concluded the following:

1 - The diversity of motives and objectives clearly affected the writings of historians.

2 - The emergence of many types of history writing

3 - The religious, cultural and intellectual motives are the most important for Moslem historians in history writing

4 - Political, administrative and economic motives and objectives played an important role in boosting history writing

5 - Social connections had clear impact on the efforts of some historians to commemorate their tribes and families and their achievements.

6 - A number of historians adopted an accurate scientific approach to write down and verify the historical information, giving clear objectives for history writing.

\section{Sources \& References:}

1 - Al Asbahani, Abu Naeem Ahmad (died in $430 \mathrm{AH}$ ), (1967), Hilyat Al Awliya WA Tabaqat AlAsfiyaa, Beirut, edition 1 .

2 - Al Bukhari , Abu Abdullah Mohammad Bin Ismaeel 
(died in $256 \mathrm{AH})$,(1422 AH ), Sahih Al Bukahri, Beirut, Verification by : Mohammad Zuhair Bin Naser Al Naser, Edition 1, House of Tawq Al AlNajah.

3 - Al Balathri, Ahmad Bin Yahya Bin Jaber Bin Dawood ( died in 279 ), (1988), Fotooh Al Bildan, Beirut, Conquests of countries, Al Hilal house and bookshop . 4 - Ibn Hajar, Abu Al Fadhl Ahmad Bin Ali Al Asqalani (died in 852 AH), ( 2002), Lisan Al Mizan, Beirut, Verification by: Abdulfatah Abu Ghada, Edition 1, Islamic Bashaer House.

5 - Hammadi, Mohammad Jasim, Mawared Al Balathri on Omayyad Dynasty on writing the genealogy of the nobles, Doctorate Degree written on typewriter, submitted to faculty of Literature, Baghdad University.

6 - Al Douri, AbdulAziz, (1981), A research on the establishment of science of history by the Arabs, Beirut, Edition 1, Orient house.

7 - Al Dinori, Abu Mohammad Abdullah Bin Moslem Bin Qutayba (died in 276 AH),( 2010) Oyon Al Akhbar, Beirut, Edition 1, Scientific books house.

8 - Al Dhahabi, Shams Al Dean Abu Abdullah Mohammad Mohammad Bin Ahmad (died in 748AH), (2003), History of Islam, death of the famous and scholars, Verification by : Dr. Bashar Awad Maarof, Beirut, Edition 1, Al Gharb Islamic house .

9 - Ibn Saad, Mohammad Bin Manee (died in $230 \mathrm{AH}$ ), Al 
Motives Affecting History Writing During the Period

Tabaqat Al Kubra, Beirut, Sader house.

10 - Saeed, Mohammad Ata Allah Mohammad, (1996), intentions of Moslem historians for writing of biographies in the second and third century $A H$, Master's Thesis, written on typewriter submitted to faculty of literature, Bagdad University,.

11 - Al Tabari, Abu Jafar muhammad Bin Jarir (died in 310 AH),( 1387 AH), History of prophets and Kings, Beirut, Edition 2, Heritage House.

12 - Al Waqidi, Mohammad Bin Omar (died in 207AH), (1996), Al Maghazi (Conquests), Cairo, Verification by: Marson Johns, Edition 1.

13 - Al - Leheabi, Saleh Muhammad Zeki,( 2007)Al Trateeb Al Nabawiya, Historical study based on Sahih Al Bukhari, Dubai, Edition 1 ,Quran international prize.

14 - Al - Leheabi , Saleh Muhammad Zeki , (2014 ), Administrative and economic systems in the era of the Prophet (PBUH) , A historical study based on Sahih Moslem, Dubai, Edition 1,Al Ajwad publishing and Distribution establishment.

15 - Maskoweh , Abu Ali Ahmad Bin Mohammad Bin Yaqob ( died in 421 AH ), (2003), Tajarob Al Omam wa Taaqob Al Himam, Beirut, Verification by : Sayed Kisrawi Hasan, Edition 1 ,Scientific Books House .

12- Ibn Al Nadem, Mohammad Bin Ishaq (died 


\section{Dr. Saleh Muhammad Zeki Mahmood Al - Leheabi}

approximately in $385 \mathrm{AH}$ ), Al Fahrast, Cairo, Edition 1, without a date.

17 - Al Nawawi , Abu Zakariya MohyiEdin Yahya Bin Sharaf ( died in $676 \mathrm{AH}$ ), Tahtheeb Al Asma wa Allughat, Egypt , Sharakat Al OlamaawaIdarat Al Tibaa Al muniriya, without date.

18 - Ibn Hisham, Abdul malik Al Maafri (died in 213AH), (1955), Al Sera Al Nabawiya ( Prophet's Biography ), Egypt, Verification by : Mostfa Al Saqa , Ibrahim Al Ibyari and Abdul hafeeth Al Shalabi, Edition 2, Company, bookshop and printing press of Mostafa Al Babi Al Halabi and Sons.

19 - Horvitz, Yousef , (1949), First Conquests and their authors, Cairo, Translation : Husain Nasar, Edition 1, Printing press of Mostafa Al Babi Al Halabi \& Sons , .

20 - Al Yaqobi , Ahmad Bin Abi Yaqoub ( died in 259), (1995 ) Al Tareekh( History), Beirut, Verification by : Mohammad Yousef Najm, Edition 1, Sader printing and publication house .

21 - Abu Yousef, Yaqoub Bin Ibrahim Bin Habib AlAnsari (died in $182 \mathrm{AH}$ ), Al Kharaj ( Land Tax ), Egypt, Verification by : Taha Abdulraoof Saad, and Saad Hasan Mohammad, without edition number, Azhariay Torath bookshop, without date ) . 